\title{
Targeting MET kinase with the small-molecule inhibitor amuvatinib induces cytotoxicity in primary myeloma cells and cell lines
}

Cornel Joseph Phillip ${ }^{1,6+}$, Shadia Zaman ${ }^{1 \dagger}$, Shujun Shentu', Kumudha Balakrishnan ${ }^{1,6}$, Jiexin Zhang ${ }^{2}$, Veera Baladandayuthapani ${ }^{3,6}$, Pietro Taverna ${ }^{7}$, Sanjeev Redkar ${ }^{7}$, Michael Wang ${ }^{5}$, Christine Marie Stellrecht ${ }^{1,6+}$ and Varsha Gandhi ${ }^{1,4,6^{*}+}$

\begin{abstract}
Background: MET is a receptor tyrosine kinase that is activated by the ligand HGF and this pathway promotes cell survival, migration, and motility. In accordance with its oncogenic role, MET is constitutively active, mutated, or over-expressed in many cancers. Corollary to its impact, inhibition of MET kinase activity causes reduction of the downstream signaling and demise of cells. In myeloma, a B-cell plasma malignancy, MET is neither mutated nor over-expressed, however, HGF is increased in plasma or serum obtained from myeloma patients and this was associated with poor prognosis. The small-molecule, amuvatinib, inhibits MET receptor tyrosine kinase. Based on this background, we hypothesized that targeting the HGF/MET signaling pathway is a rational approach to myeloma therapy and that myeloma cells would be sensitive to amuvatinib.
\end{abstract}

Methods: Expression of MET and HGF mRNAs in normal versus malignant plasma cells was compared during disease progression. Cell death and growth as well as MET signaling pathway were assessed in amuvatinib treated primary myeloma cells and cell lines.

Results: There was a progressive increase in the transcript levels of HGF (but not MET) from normal plasma cells to refractory malignant plasma cells. Amuvatinib readily inhibited MET phosphorylation in primary CD138+ cells from myeloma patients and in concordance, increased cell death. A 48-hr amuvatinib treatment in high HGF-expressing myeloma cell line, U266, resulted in growth inhibition. Levels of cytotoxicity were time-dependent; at 24, 48, and $72 \mathrm{~h}$, amuvatinib (25 $\mu \mathrm{M})$ resulted in $28 \%, 40 \%$, and $55 \%$ cell death. Consistent with these data, there was an amuvatinib-mediated decrease in MET phosphorylation in the cell line. Amuvatinib at concentrations of 5, 10, or $25 \mu \mathrm{M}$ readily inhibited HGF-dependent MET, AKT, ERK and GSK-3-beta phosphorylation. MET-mediated effects were not observed in myeloma cell line that has low MET and/or HGF expression.

Conclusions: These data suggest that at the cellular level MET/HGF pathway inclines with myeloma disease progression. Amuvatinib, a small molecule MET kinase inhibitor, is effective in inducing growth inhibition and cell death in myeloma cell lines as well as primary malignant plasma cells. These cytostatic and cytotoxic effects were associated with an impact on MET/HGF pathway.

Keywords: MET, HGF, amuvatinib, MP470, Multiple myeloma

\footnotetext{
* Correspondence: vgandhi@mdanderson.org

${ }^{\dagger}$ Equal contributors

'Departments of Experimental Therapeutics, The University of Texas MD

Anderson Cancer Center, Houston, Texas, USA

${ }^{4}$ Leukemia, The University of Texas MD Anderson Cancer Center, Houston,

Texas, USA

Full list of author information is available at the end of the article
} waiver (http://creativecommons.org/publicdomain/zero/1.0/) applies to the data made available in this article, unless otherwise stated. 


\section{Introduction}

Multiple myeloma (MM) is an indolent B-cell disease that develops in the bone marrow and is associated with osteolytic lesions in the advanced stages [1]. Despite progress in prolonging myeloma patient survival, current therapies are not curative; thus, it is imperative that new treatments be developed for this debilitating disease $[2,3]$.

Survival and proliferation of myeloma cells are dependent on the presence of a permissive microenvironment, which includes bone marrow stroma and soluble cytokines [4-9] such as IL-6 and HGF $[8,10]$. HGF is the ligand for MET receptor tyrosine kinase. When HGF binds to and activates MET, MET is autophosphorylated on Tyr1230, Tyr1234 and Tyr1235 located in the activation loop [11-14]. In addition, MET has a multisubstrate docking site that is activated at Tyr1349 and Tyr1356. The phosphorylation of this region results in the induction of MET signaling through the activation of several downstream target pathways, including the mitogen-activated protein kinase (MAPK) and AKT signaling pathways [11]. HGF/MET-induced MAPK signaling has been shown to be essential for proliferation, migration and invasion $[7,11,15,16]$ while the induction of AKT signaling promotes tumor cell survival [17].

HGF/MET signaling is increasingly recognized as an important contributor to the pathogenesis of myeloma. Expression of both HGF and MET has been demonstrated in most myeloma cell lines and primary patient samples $[18,19]$. Studies correlating HGF levels with MM clinical parameters such as diagnosis [20-23] disease stage, aggressiveness [22,24,25], prognosis [22,23,26], and response [26-29]. Besides its effects on the malignant myeloma cells, HGF is involved in the pathogenesis of myelomarelated bone disease. HGF levels are increased in patients with extensive bone lesions, and correlates with expression of osteoclast stimulating cytokines [24]. IL-11 secretion from osteoblasts is induced by HGF [30], and HGF inhibits bone morphogenetic protein-induced osteoblastogenesis [31].

Taken together, these clinical findings strongly support our hypothesis that targeting the HGF/MET signaling pathway is a rational approach to myeloma therapy. In line with this postulate, our laboratory studies demonstrated that genetically knocking down MET in myeloma cell lines using short hairpin RNA and ribozyme approaches resulted in growth inhibition and demise of the myeloma cells $[32,33]$. Consistent with these observations, a decline in MET transcript and protein levels induced by treatment with any of the transcription inhibitors flavopiridol, cordycepin, or 8-chloro-adenosine, promoted myeloma cell death [32-34]. Collectively, these data demonstrate MET's pivotal role in myeloma cell biology and underscore the importance of MET targeting as a therapeutic strategy in MM [35].
While these genetic and pharmacologic strategies suggest utility of MET/HGF inhibition as therapeutic targets, these interventions are not pragmatic for clinical use. Amuvatinib (previously known as MP470, Astex Pharmaceuticals, Inc.) is a synthetic carbothioamide that inhibits MET, cKIT and platelet derived growth factor receptor (PDGFR). This small-molecule inhibitor competes with ATP for binding at the catalytic site. In solid cancers, amuvatinib has been shown to be effective in inhibiting MET at low micromolar concentrations $\left(\mathrm{IC}_{50} \sim 5 \mu \mathrm{M}\right)$ [36]. Amuvatinib is a well-tolerated, orally bioavailable drug currently in phase II clinical trials $[37,38]$. Availability of a clinical candidate, its inhibitory potential for MET kinase, and the role of MET in myeloma cell survival provided compelling rationales for testing the effects of amuvatinib on myeloma cells.

In the present study, we compared mRNA levels of $M E T$ and $H G F$ in normal and primary myeloma plasma cells. We investigated amuvatinib's actions and cytotoxic effects in primary plasma cells obtained from patients with myeloma. To elucidate in more detail the mechanism of action of amuvatinib in myeloma cells, we evaluated its effect on MET activity and downstream signaling in the myeloma cell line U266, which over-expresses HGF. Our data demonstrate that MET receptor tyrosine kinase may be targeted in myeloma and support the investigation of small-molecule inhibitors such as amuvatinib as possible therapeutic agents against this disease.

\section{Results}

Expression levels of MET and HGF mRNA in bone marrow plasma cells of healthy donors and patients

Previously studies have correlated plasma HGF levels with MM clinical parameters such as diagnosis [20-23] disease stage, aggressiveness [22,24,25], prognosis [22,23,26], and response [26-29]. While expression of both HGF and $M E T$ transcripts has been shown to be present in myeloma cells $[18,19]$ and HGF mRNA has also been demonstrated to be expressed in bone marrow stromal cells [39] the levels of $H G F$ and MET $m R N A$ in patient plasma cells have not been well evaluated nor correlated with disease status.

To determine the levels of MET and HGF gene expression in malignant and normal plasma cells, we analyzed data from the Mayo Clinic Patient Dataset available in the public domain $[40,41]$. The 162 samples evaluated represented 15 healthy individuals (normal), 22 patients with monoclonal gammopathy of undetermined significance (MGUS), 24 with smoldering MM (SMM), 74 with newly diagnosed MM (MM-N), and 27 with relapsed/refractory $M M(M M-R)$. Among these five groups, there was no significant difference $(P=0.708)$ in the expression of $M E T$ in the CD138+ cells (Figure 1A). In contrast, there was a significant trend $\left(P=2.5 \times 10^{-06}\right)$ for 

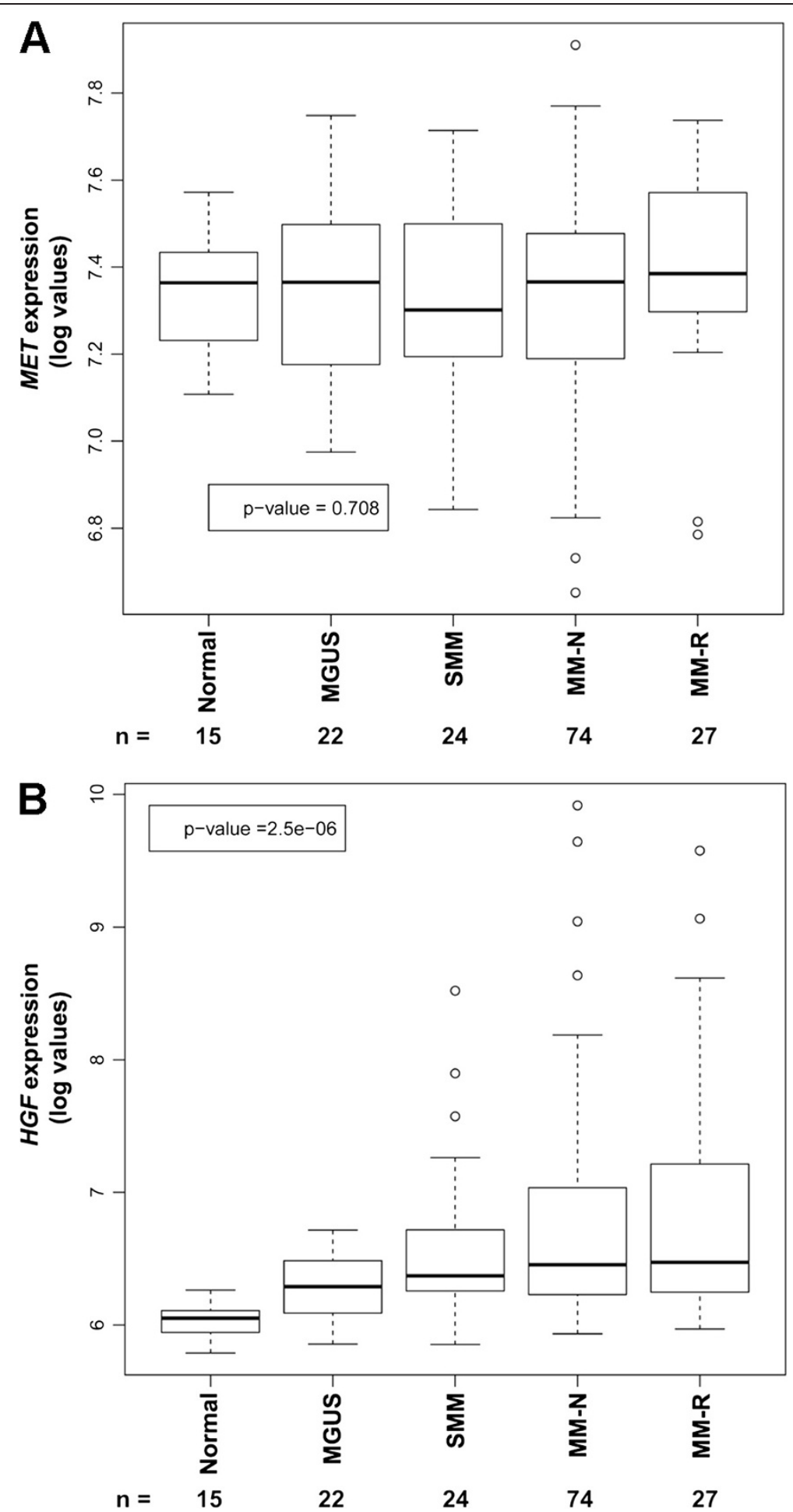

Figure 1 Expression levels of $H G F$ mRNA, but not MET, in CD138+ cells increase progressively from healthy individuals to myeloma patients. Publically available expression array data was Robust Multichip Average processed and plotted as boxplots of relative (A) MET and (B) HGF mRNA log expression values in healthy donors (normal), and in patients with monoclonal gammopathy of undetermined significance (MGUS), smoldering multiple myeloma (SMM), newly-diagnosed multiple myeloma (MM-N), or relapsed/refractory disease (MM-R). Boxplots show 25th and 75th percentiles and the bold lines as medians. Whiskers show the range of values within the interquantile range from the box, and circles are outliers. Numbers at the bottom of each graph indicate the number of individuals in each category. 
increases in HGF mRNA levels in CD138+ plasma cells, with progressive severity of disease from healthy donors to patients with relapsed or refractory MM (Figure 1B). Within each group, there was heterogeneity in $H G F$ expression as evinced by the 75th percentile mark. It is interesting to note that even samples with lower $H G F$ mRNA levels in the plasma cells, typically had higher levels than the samples from healthy individuals; the 25th percentile for the myeloma patient HGF levels was > the 75th percentile for healthy individuals.

\section{Induction of apoptosis by amuvatinib in primary CD138+ and CD138- Cells}

Gene array analysis along with numerous other studies by us $[32,33]$ and others $[22,23,26]$, identified the HGF/ MET axis as a therapeutic target in myeloma. To test this, we assessed the sensitivity of primary myeloma cells to the MET-kinase inhibitor, amuvatinib. CD138+ (myeloma plasma cells) and CD138- (non-malignant cells) cells were isolated from bone marrow samples obtained from eight myeloma patients (Table 1) and treated with $25 \mu \mathrm{M}$ amuvatinib for $24 \mathrm{~h}$. This dose was chosen based on findings that $>95 \%$ of the compound is bound and sequestered by serum proteins (unpublished data) as well as a small preliminary screen in myeloma cell lines (data not shown). CD138+ cells from six out of eight patient samples showed a cell death induction in the amuvatinib treated cells compared to time-matched dimethyl sulfoxide (DMSO)-treated control cells as measured by annexin V/propidium iodide (PI) staining (Figure 2A). Cell death in these six samples increased by $20 \%$ to $67 \%$ compared to time-matched controls; patients 3 and 5 showed $<10 \%$ increase in cell death.

An assessment of clinical characteristics of the myeloma patients did not reveal any correlations with amuvatinib-induced cell death, including prior treatment, patient age, or cellularity of the bone marrow (Table 1). We were able to measure the HGF levels in plasma samples from patients 2,4 , and 5 which were
$11.9,1.7$, and $1.4 \mathrm{ng} / \mathrm{mL}$, respectively. Although the number of total samples is small, there seems to be a relationship between levels of HGF and amuvatinibinduced apoptosis. Additional studies are needed to determine if there is any correlation between HGF level and sensitivity of CD138+ cells to MET inhibition.

In contrast to the sensitivity of CD138+ cells to amuvatinib, CD138- cells did not show any sizeable inductions (all, <10\%) of death compared to time-matched controls (Figure 2B), suggesting that non-malignant bone marrow cells are not affected by amuvatinib. Overall, these results indicate that treatment of CD138+ MM cells with a MET inhibitor is detrimental to their survival.

\section{Effect of Amuvatinib on MET signaling in CD138+ and CD138- cells}

To determine whether death of CD138+ cells was associated with an effect on the target, total and phosphorylatedMET (p-MET) expression levels were determined by flow cytometry. There were sufficient numbers of cells from patients 6 and 8 to perform this assessment. In both samples, MET phosphorylation was reduced on Tyr 1234/1235 in the CD138+ cells by $40 \%$ and $50 \%$, respectively, as compared to the time-matched controls (Figure $3 \mathrm{~A}$ and $\mathrm{B}$ ). In contrast, there was no detectable level of p-MET in CD138- cells from patient 8 as compared to isotype control (Figure 3C). The lack of p-MET in CD138- cells likely explains why this population of cells was not affected by amuvatinib treatment in any of the eight patient samples.

\section{Effect of Amuvatinib on Growth Inhibition}

Since the number of the primary CD138+ cells in eight patient samples were insufficient for performing a detailed investigation of HGF/MET signaling, we decided to further investigate the effects of amuvatinib in a myeloma cell line. Because our results in the patient samples suggested that higher levels of HGF may be associated with an increased sensitivity to MET inhibition, we used the U266 cell line which expresses high levels of HGF

Table 1 Myeloma patient characteristics

\begin{tabular}{|c|c|c|c|c|c|c|c|}
\hline $\mathrm{Pt} \#$ & Age (yrs) & Sex & Ethnicity & $\mathrm{WBC}^{a}\left(10^{3} / \mu \mathrm{l}\right)$ & Plasma cells (\%) & $\mathrm{BM}^{b}$ aspirate done & Outcome of treatment \\
\hline 1 & 62 & Male & White & 3.6 & 7 & At diagnosis & $N A^{c}$ \\
\hline 2 & 53 & Female & Black & 2.0 & 74 & $\begin{array}{l}\text { Post bortezomib + doxorubicin + lenalidomide + } \\
\text { dexamethasone }\end{array}$ & Progressive \\
\hline 3 & 53 & Female & White & 6.3 & 4 & Post 3 cycles bortezomib + dexamethasone & Near complete remission \\
\hline 4 & 76 & Female & White & 4.4 & 2 & $\begin{array}{l}\text { Post cyclophosphamide + lenalidomide + } \\
\text { dexamethasone }\end{array}$ & Progressive \\
\hline 5 & 58 & Female & Hispanic & 9.1 & 8 & At diagnosis & NA \\
\hline 6 & 64 & Female & White & 12.5 & 49 & At diagnosis & NA \\
\hline 7 & 71 & Male & White & 3.9 & 32 & NA & NA \\
\hline 8 & 76 & Male & White & 4.9 & 36 & post 1 yr auto stem cell transplant & Progressive \\
\hline
\end{tabular}

${ }^{a}$ white blood cells; ${ }^{b}$ bone marrow; ${ }^{c}$ not applicable. 

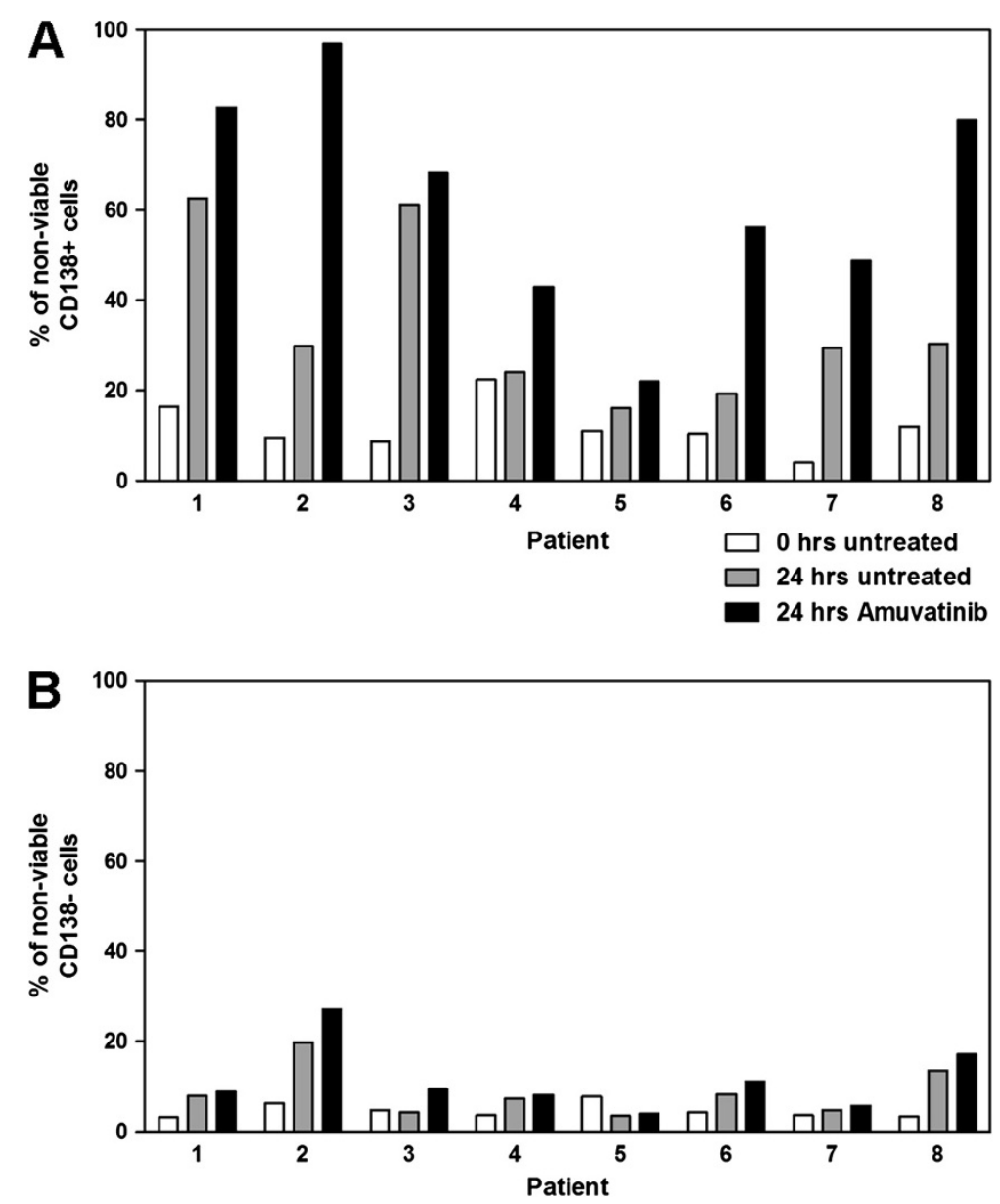

Figure 2 Amuvatinib induces apoptosis in CD138+, but not CD138- cells. (A) CD138+ and (B) CD138- cells isolated and purified from bone marrow samples of eight myeloma patients were stained with annexin V/PI and assessed by flow cytometry initially after isolation (white bars) or after $24 \mathrm{~h}$ of treatment with vehicle (gray bars) or $25 \mu \mathrm{M}$ amuvatinib (black bars).

[19]. Compared to DMSO-treated control cells, amuvatinib-treated U266 cells showed a dose- and timedependent decrease in growth (Figure 4A). The growth inhibition was $\sim 40 \%$ at a dose of $5 \mu \mathrm{M}$ after 48 and $72 \mathrm{~h}$ of incubation and $50 \%$ at a dose of $\sim 7 \mu \mathrm{M}$ at $72 \mathrm{~h}$.

\section{Effect of Amuvatinib on cell cycle arrest and DNA synthesis}

We also tested whether the observed amuvatinibinduced growth inhibition was associated with an alteration in the cell cycle. At low micromolar doses (3 and $5 \mu \mathrm{M})$, U266 cells were arrested at $\mathrm{G}_{1}$ after 48 and $72 \mathrm{~h}$ (Figure $4 \mathrm{~B}$ and $\mathrm{C}$ ). In the DMSO-treated controls, approximately $65 \%$ of cells were in $G_{1}$ phase at $72 \mathrm{~h}$, while cells treated $3 \mu \mathrm{M}$ amuvatinib significantly increased to $75 \%$ in $\mathrm{G}_{1}$ phase at the same time point $(p<0.05)$. Incubation with a higher level of amuvatinib $(25 \mu \mathrm{M})$ resulted in a lower percentage of cells in $G_{1}$ phase (Figure $4 \mathrm{C}$ ), with a concomitant increase in the subG $\mathrm{G}_{1}$ fraction (data not shown).
To determine whether the observed cell cycle changes were associated with an effect on DNA synthesis, we measured incorporation of thymidine in total DNA. Compared to DMSO-treated (control cells), amuvatinibtreated cells had decreased thymidine incorporation at doses of both 5 and $25 \mu \mathrm{M}$ (Figure 4D), which was significantly higher for cells treated with $5 \mu \mathrm{M}$ amuvatinib for 24 and $72 \mathrm{~h},(P=0.008$ and $P=0.048$, respectively). At $24 \mathrm{~h}$, the inhibition of thymidine incorporation was greater than $50 \%$ with $5 \mu \mathrm{M}$ amuvatinib. Additionally, as expected, the decrease in the cells' S-phase DNA replicative capacity was discernible $24 \mathrm{~h}$ before there was a measurable change in the cell cycle profile as the doubling time for U266 cells is $\sim 36$ hours.

\section{Induction of Apoptosis by Amuvatinib}

Similar to what was seen in the primary CD138+ cells, U266 cells treated with $25 \mu \mathrm{M}$ amuvatinib exhibited significantly greater cell death $(28 \%, 40 \%$, and $54 \%)$ than DMSO-treated controls (6\%, 7\%, and 7\%) for 24,48 , and 


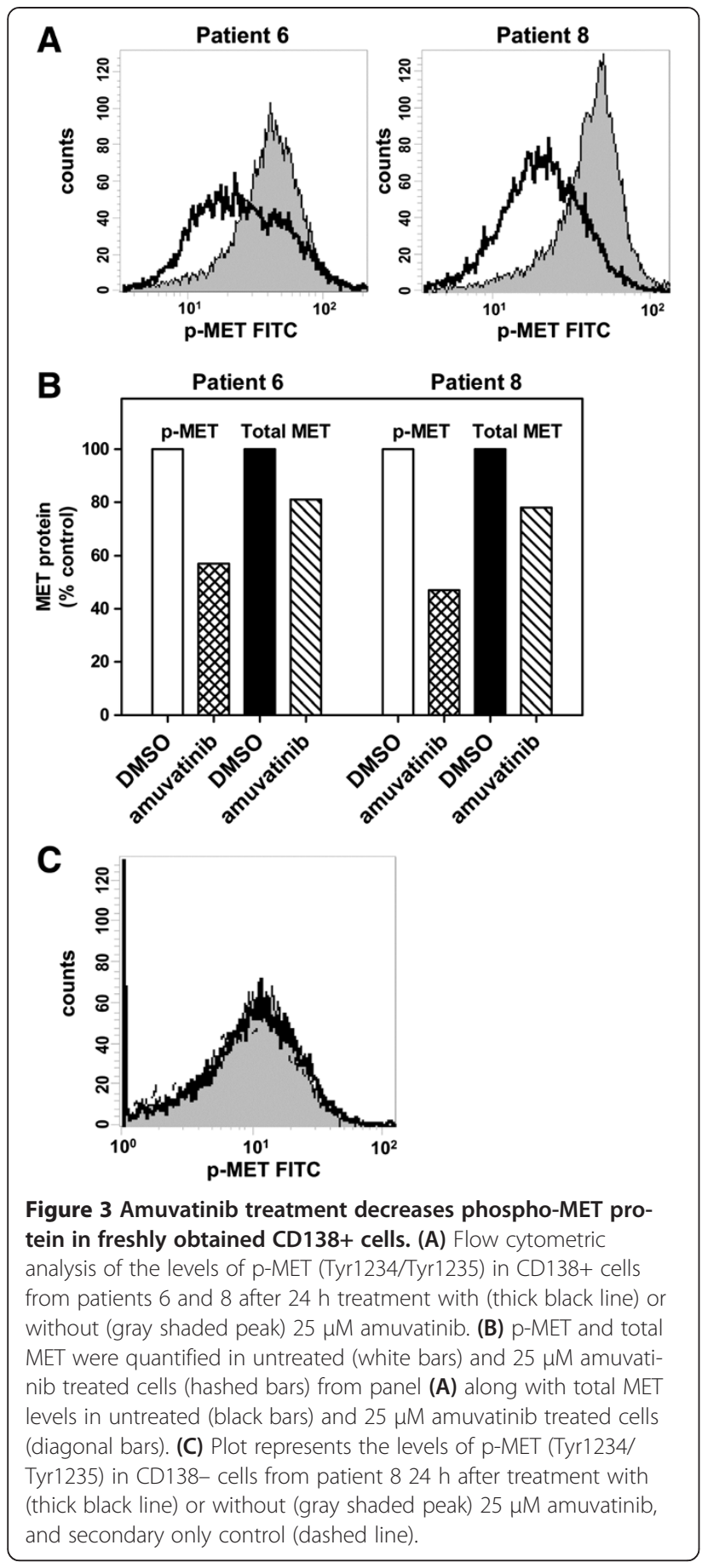

$72 \mathrm{~h}$, respectively (Figure $5 \mathrm{~A}$ and $\mathrm{B})(P=0.045,0.015$, and 0.018 respectively). This apoptotic induction was blocked by a pan-caspase inhibitor, ZVAD, suggesting a role for caspases in amuvatinib-mediated cell death (data not shown). Consistent with the annexin V/PI staining results was our finding that amuvatinib induced poly $\mathrm{ADP}$ ribose polymerase (PARP) cleavage in these cells in a dose-dependent manner. Under full serum conditions (10\% fetal bovine serum (FBS)), an induction of PARP cleavage was seen after $24 \mathrm{~h}$ with doses as low as $3 \mu \mathrm{M}$ amuvatinib with the highest level of cleaved PARP product was seen at $25 \mu \mathrm{M}$ (Figure $5 \mathrm{C}$ ).

Because $95 \%$ of amuvatinib binds serum proteins and is unavailable to the cells, we also examined the efficacy of amuvatinib under low serum $(0.1 \%$ FBS $)$ conditions. When cells were treated with $5 \mu \mathrm{M}$ amuvatinib for 16 hours in the presence of low serum, but in the presence of endogenous autocrine HGF, we found maximum induction of PARP cleavage (Figure 5D). To further confirm the cytotoxic effects of amuvatinib in myeloma cells is associated with inhibiting the HGF/MET signaling axis, we compared the efficacy of amuvatinib to induce apoptosis in U266 cells versus RPMI-8226/S, a myeloma cell line which express 75\% lower levels of HGF and 95\% lower levels of MET (Additional file 1: Figure S1). As expected, there was a significant amuvatinib dosedependent apoptosis-induction in the U266 cells after $48 \mathrm{~h}$ treatment (Figure $5 \mathrm{E})(25 \mu \mathrm{M}$ versus $0,2.5,5$, and $10 ; P=0.022,0.018,0.013$, and 0.029 , respectively). In contrast there was only a minor apoptosis induction in the RPMI-8226/S cells which was not statistically significant $(P=0.053,0.300,0.427$, and 0.503, respectively). These results suggest that the apoptosis induction is due to targeting MET kinase which U266 cells are addicted to while RPMI-8226/S cells are not.

\section{Tumoricidal Effects of Amuvatinib in Myeloma Cells Grown in a Protective Stromal Environment}

Bone marrow stroma provides a protective environment for MM cells [42]; thus, it is important to assess the efficacy of therapeutic agents in the context of a stromal environment. To assess this, we treated U266 cells cocultured with and without stromal cells with amuvatinib for $48 \mathrm{~h}$ and measured viability by using flow cytometry analysis of annexin V/PI staining. Under these conditions, the U266 do not attach to the stromal cells, but are protected by them through both cell to cell contact and by various soluble factors produced by the stromal cells [43]. Amuvatinib induced $~ 50 \%$ cell killing during this time period and co-culture with the stromal cells provided no protection from this effect (Figure 5F). In contrast, these stromal cells were able to protect U266 cells from bortezomib treatment as they reduced the amount of bortezomib-induced apoptosis from $\sim 75 \%$ to $\sim 40 \%$ (Additional file 1: Figure S2A). To determine whether amuvatinib had an effect on the survival of stromal cells, stromal cells cultured alone were treated with amuvatinib, harvested by trypsinization, and similarly assessed for viability. Interestingly, amuvatinib had a very minimal effect on the survival of this population of cells (Figure 5F), though they express MET (Additional file 1: Figure S2B). These results indicate that the tumoricidal action of amuvatinib was largely restricted to the 


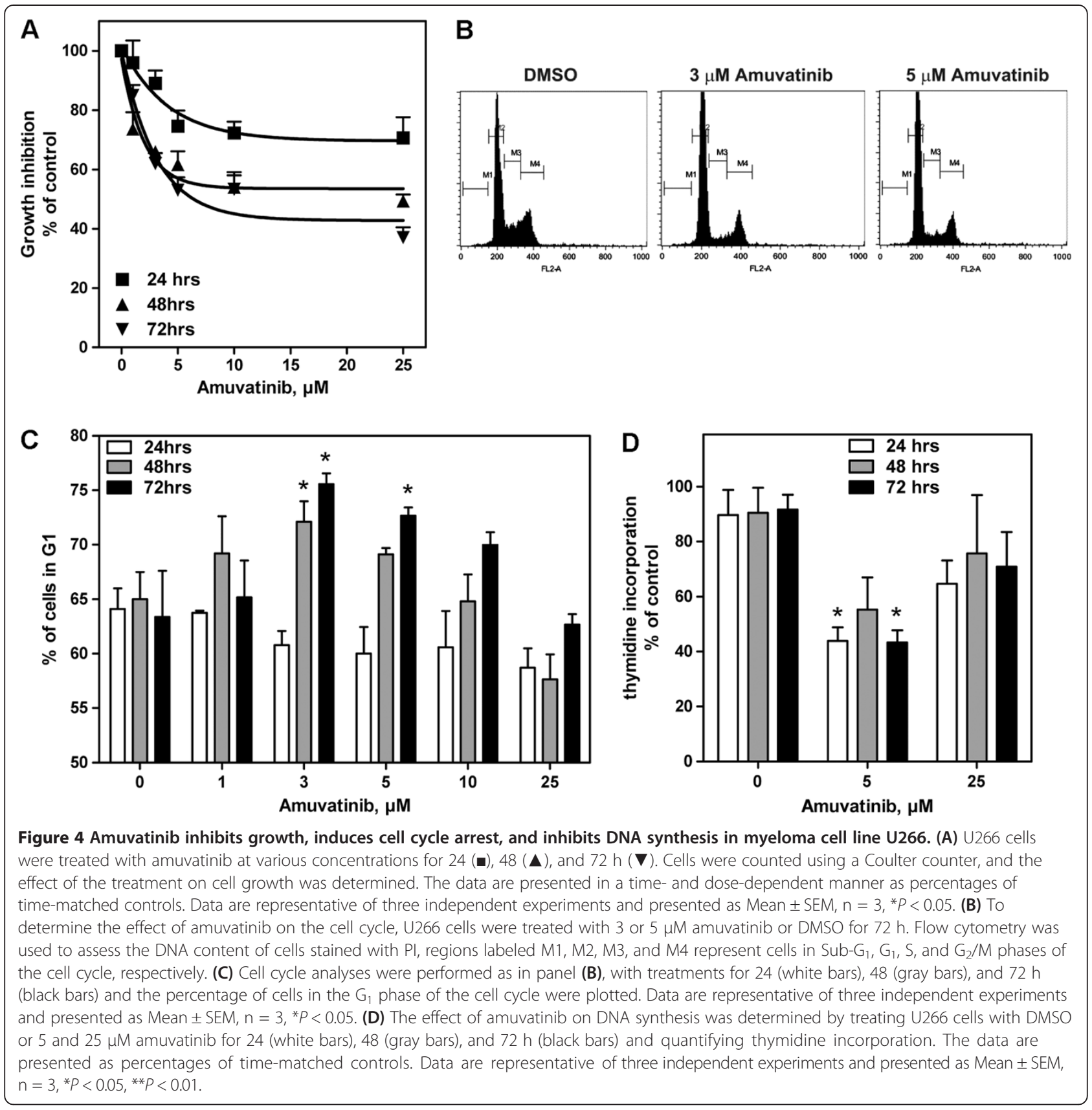

U266 myeloma cells, whereas the stromal cells, which are not addicted to MET, are not affected by this inhibitor. Furthermore, the stromal cells were not able to protect the U266 cells from amuvatinib's tumoricidal activity.

Since amuvatinib also inhibits PDGFR and KIT, we validated MET kinase inhibition as the primary cause of cell death by using imatinib as a negative control. In addition to ABL, imatinib is known to also inhibit PDGFR and KIT but not MET [44]. In contrast to amuvatinib, $25 \mu \mathrm{M}$ imatinib did not induce significant cell death (Figure 5G; $P=$ 0.07 ) indicating that amuvatinib-mediated cell death is not due to its effects on PDGFR and KIT.

\section{Effect of Amuvatinib on MET Protein}

To further investigate the effect of amuvatinib on MET signaling, we first measured MET receptor tyrosine kinase activity in U266 cells by flow cytometry. Similar to the results seen with the CD138+ cells from the patient samples, a reduction in MET phosphorylation was detected in cells treated for $24 \mathrm{hr}$ with $25 \mu \mathrm{M}$ amuvatinib when cells are grown in normal growth conditions $(10 \%$ FBS) (Figure 6A and B). This decrease of p-MET was associated with cell death as cell death was induced with $25 \mu \mathrm{M}$ amuvatinib when cells are grown in normal growth conditions (10\% FBS) (Figure 5B). 


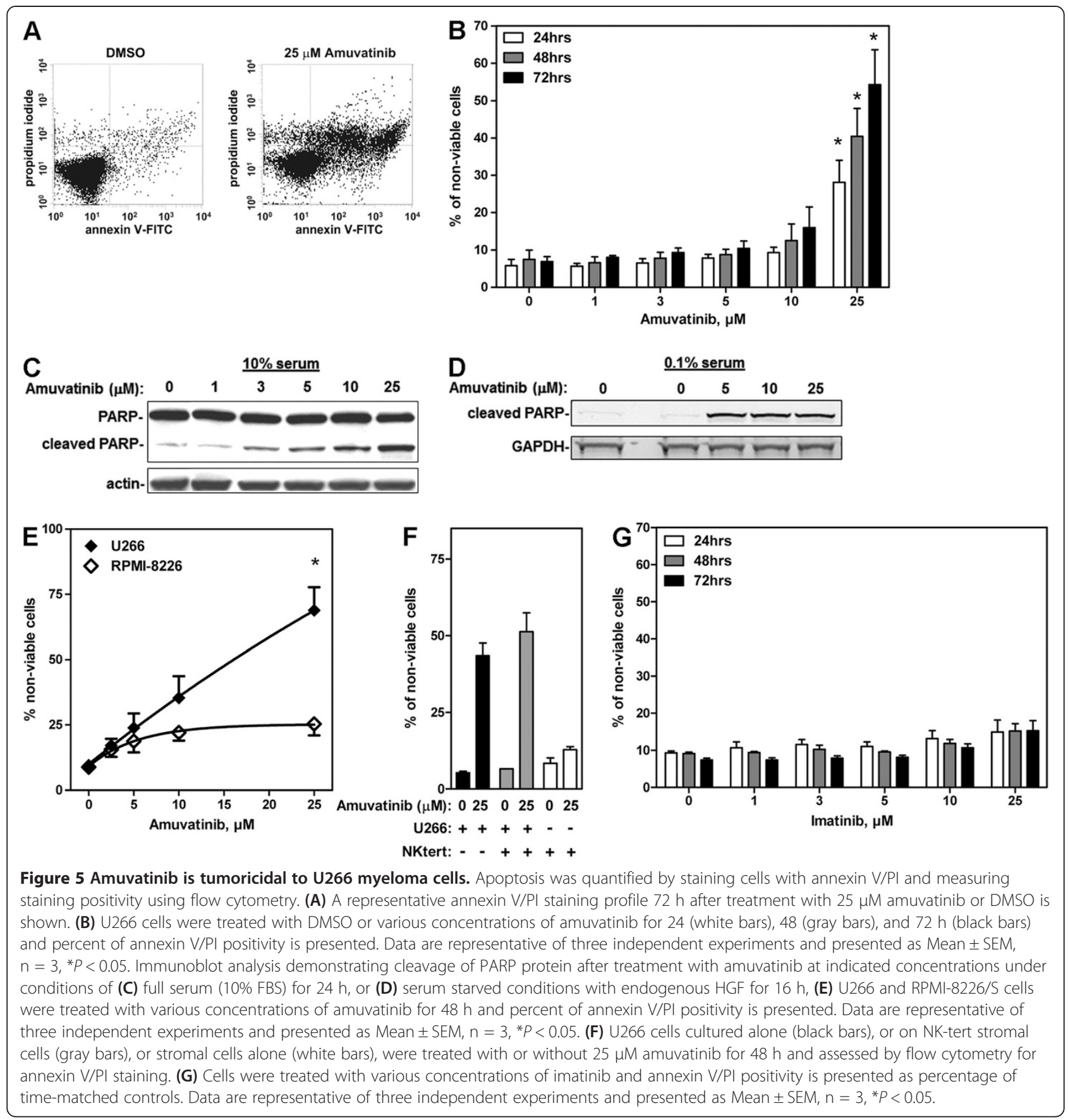

To assess the effects of amuvatinib on HGF-specific signaling, protein lysates from U266 cells serum starved in $0.1 \%$ FBS for $16 \mathrm{~h}$ with and without various concentrations of amuvatinib followed with 15 min HGF stimulation were examined by immunoblot analysis. The results showed that under serum starved conditions, treatment with $5 \mu \mathrm{M}$ amuvatinib, decreased phosphorylation of the processed $\sim 140 \mathrm{kDa}$ MET $\beta$-chain at Tyr1349 by $~ 60 \%$ (Figure $6 \mathrm{C}$ and $\mathrm{D}$ ). Because of the autocrine stimulation of MET by the endogenous HGF produced in these cells,
MET was phosphorylated under serum-starved conditions even without the addition of exogenous HGF. Furthermore, an amuvatinib-dependent decrease of total MET levels of $\sim 30 \%$ was also observed. A $\sim 170 \mathrm{kDa}$ phosphorylated MET band was detected at $\sim 2$ fold higher levels than the $140 \mathrm{kDa}$ band in untreated U266 cells. A comparison with total MET shows both bands were present but the levels of the total $140 \mathrm{kDa}$ band was 4 times greater than the levels of the $170 \mathrm{kDa}$ band. Although unprocessed pro-MET, containing both 

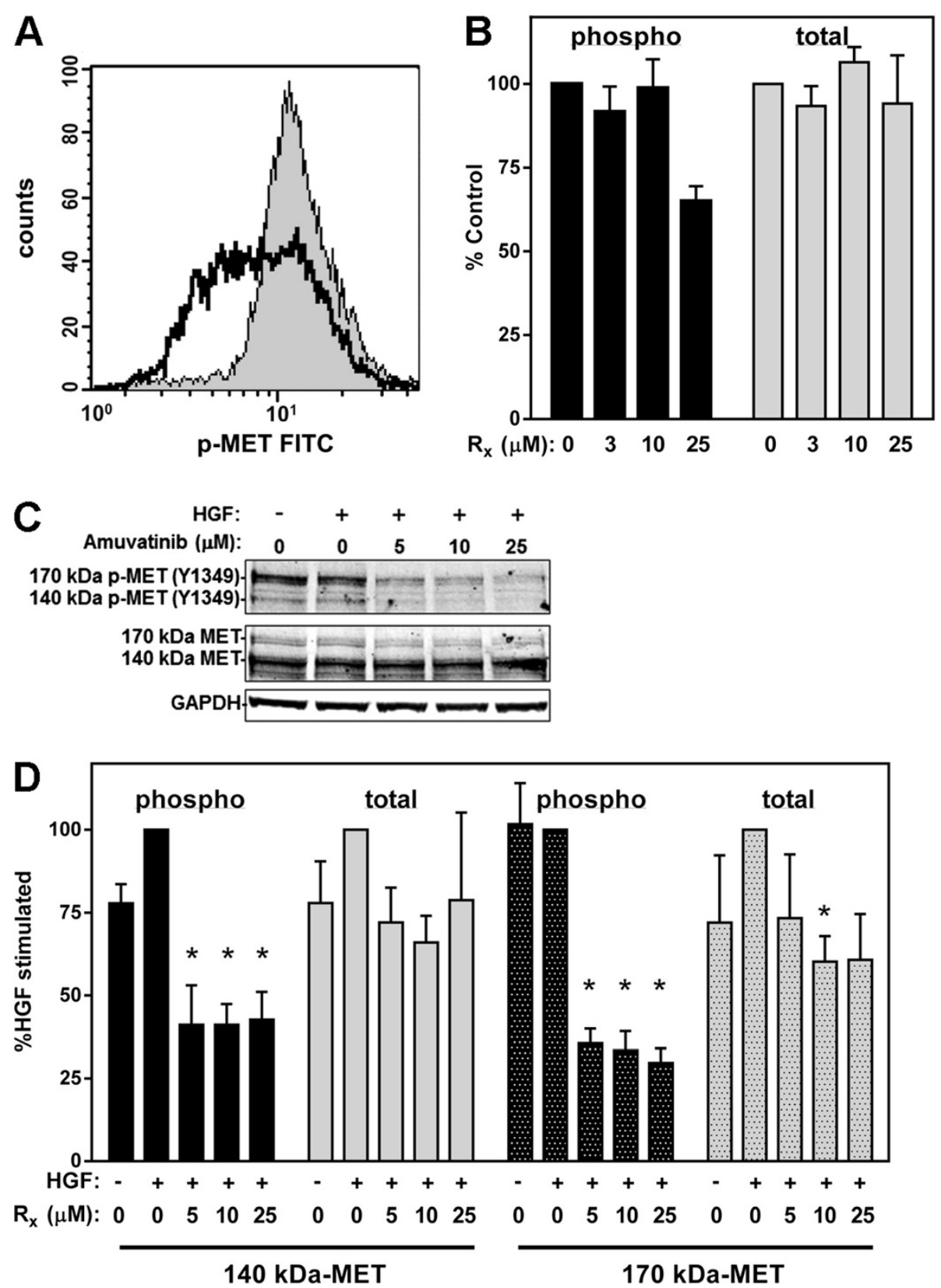

Figure 6 Amuvatinib suppresses MET receptor tyrosine kinase activity. (A) Flow cytometry analysis of p-MET (Tyr1234/1235) levels in U266 cells were treated for 24 hrs with DMSO (gray shaded) and $25 \mu \mathrm{M}$ amuvatinib (dark black line). (B) Quantification of phospho (black bars) and total (gray bars) MET staining in U266 cells treated with the indicated concentrations of amuvatinib (Rx) from quadruplet experiments as in (A). (C) U266 cells were serum starved and treated with the indicated concentrations of amuvatinib or DMSO and stimulated with $50 \mathrm{ng} / \mathrm{ml} \mathrm{HGF}$ for $15 \mathrm{~min}$. Cell lysates were subjected to immunoblot analysis to assess MET (Y1349) phosphorylation. (D) The $140 \mathrm{kDa}$ (solid bars) and the $170 \mathrm{kDa}$ (speckled bars) phospho (black bars) and total (gray bars) MET bands from triplicate experiment as in (C) were quantitated and normalized to GAPDH levels. The results are presented as percentages of the HGF-stimulated DMSO controls. Data are representative of three independent experiments and presented as Mean $\pm \mathrm{SEM}, \mathrm{n}=3,{ }^{*} P<0.05,{ }^{*} P<0.01$.

the $\alpha$ and $\beta$ subunits, has been detected by SDS PAGE as a $170 \mathrm{kDa}$ band, it has not been associated with kinase activity. Conversely, a splice variant of $M E T$ containing an additional 54 nt of exon 10 has been reported to be expressed at low levels [45]. This splice form produces a
MET isoform that has kinase activity, though it cannot be processed into $\alpha$ and $\beta$ subunits. In U266 cells, amuvatinib inhibited phosphorylation of a $170 \mathrm{kDa}$ MET by $~ 70 \%$ (Figure 6C and D, B). Again, the decrease of HGF-specific phosphorylation of both isoforms of MET under low 
serum conditions is associated with cell death under low serum conditions (Figure 5D). The lower concentration of amuvatinib needed to decrease MET phosphorylation under $0.1 \%$ serum versus $10 \%$ serum conditions is in agreement with binding of the drug by serum proteins. Additionally, the concentration of amuvatinib required to decrease MET phosphorylation correlates with the concentration required to induce cell killing under either growth conditions. These results suggest the amuvatinib-induced cell death was associated with reduced MET activity.

\section{Effect of Amuvatinib on downstream targets of MET}

Previous studies have shown that inhibition of MET causes a reduction in the phosphorylation of both AKT and extracellular signal-regulated kinases (ERK) $1 / 2$ in the MAPK signaling pathway [11]. The regulation of AKT activity by MET plays a prominent role in promoting cell survival. Moreover, MET regulation of the ERK pathway is important for proliferation and both the ERK1/2 and AKT pathways are involved in METinduced cell spreading and motility. To examine AKT activity, p-AKT (S473) levels were measured in U266 cells by flow cytometry. Similar to the results seen with p-MET, a reduction in AKT phosphorylation was detected in cells treated for $24 \mathrm{hr}$ with $25 \mu \mathrm{M}$ amuvatinib when cells were grown in normal growth conditions (10\% FBS) (Figure 7A and B). An assessment of amuvatinib's effects on HGF-specific signaling was also performed in the U266 cells cultured in $0.1 \%$ FBS for $16 \mathrm{~h}$ with and without various concentrations of amuvatinib followed with 15 min HGF. Immunoblot analysis again showed that lower concentrations amuvatinib is needed to decreased AKT phosphorylation at Ser473 (Figure 7C and D), even though in these cells the levels were low and difficult to detect. Interestingly, total AKT decreased by $60 \%$ with amuvatinib treatment. To better assess the effect of amuvatinib on the AKT pathway, we examined the phosphorylation of an AKT target, glycogen synthase kinase $3 \beta($ GSK $3 \beta)$ on Ser9. Amuvatinib-treated cells showed, in addition to reduction of AKT, a $65 \%$ decrease in phosphorylation of GSK3 $\beta$, with a $24 \%$ decrease in total GSK3 $\beta$ (Figure 7C and E).

A similar assessment of phospho-ERK1/2 levels under HGF specific signaling demonstrated that amuvatinib inhibited phosphorylation of both the $44-\mathrm{kDa}$ and the $42-\mathrm{kDa}$ ERK isoforms by $55 \%$ and $50 \%$, respectively, while total ERK1/2 levels did not significantly change (Figure 7C and F). These results demonstrate that amuvatinib treatment inhibits both ERK1/2 and AKT signaling through the MET pathway.

\section{Discussion}

MET is a receptor tyrosine kinase that is activated by the ligand HGF and has been shown to be constitutively expressed, mutated, or over-expressed in many different cancer cell types. It serves as an important factor for cell survival, migration, and motility $[7,11,15]$. Corollary to that, inhibition of MET kinase activity causes reduction of the downstream signaling that is necessary for these cells to maintain their oncogenic properties [46]. Previous studies in our laboratory showed that while MET receptor tyrosine kinase acts as a survival factor for myeloma cells [32,33], it is neither mutated nor, for the most part, over-expressed in MM. However, its ligand HGF is increased in plasma or serum obtained from myeloma patients and higher HGF level has been associated with poor prognosis [18,20,22,26]. Furthermore, HGF not only promotes growth, migration, and survival of myeloma cells, it also potentiates IL-6 effects [46].

While levels of plasma HGF have been associated with myeloma, levels of HGF and MET $m R N A$ in patient plasma cells have not been well evaluated nor correlated with disease status. Our analyses of mRNA array data $[40,41]$ demonstrated autocrine expression of HGF in CD138+ plasma cells from MM patients. This was consistent with previous report in 7 myeloma patient samples [18]. Our results further elucidated that the level of the $H G F$ expression was directly associated with disease progression.

Together, these findings provide a rationale for targeting the HGF/MET signaling axis in myeloma. Targeting HGF directly may prove difficult, since therapeutic targeting of HGF would need to be effective at elevated levels to successfully compete and inhibit the high serum HGF concentrations in myeloma patients. Therefore, using a small-molecule MET suppressor such as amuvatinib may be a viable option to target the HGF/MET pathway. Additionally, several MET inhibitors are available for clinical testing [11].

Amuvatinib is an orally available drug that is currently in clinical trials for the treatment of solid tumors $[37,38,47]$. This compound was designed, developed, and selected via a computation-driven in silico process whereby drug scaffolds were screened, docked, and fitted against a homologous model of KIT. After additional screening in biochemical and cell-based assays, amuvatinib was selected as a tyrosine kinase inhibitor with activity against wild-type and mutant KIT, MET, RET, FLT3 and PDGFR $\alpha[48,49]$. Later, amuvatinib inhibition of MET activity was found to lead to reduction of RAD51 expression and to radiosensitization of tumor cells [50].

Since amuvatinib is a small-molecule inhibitor that suppresses MET activity, we tested this agent as a proofof-concept to therapeutically target MET in myeloma. Our study demonstrated that amuvatinib was effective in inhibiting growth and DNA synthesis at low micromolar concentrations in cell lines grown under normal conditions (10\% FBS). Moreover, amuvatinib treatment resulted 


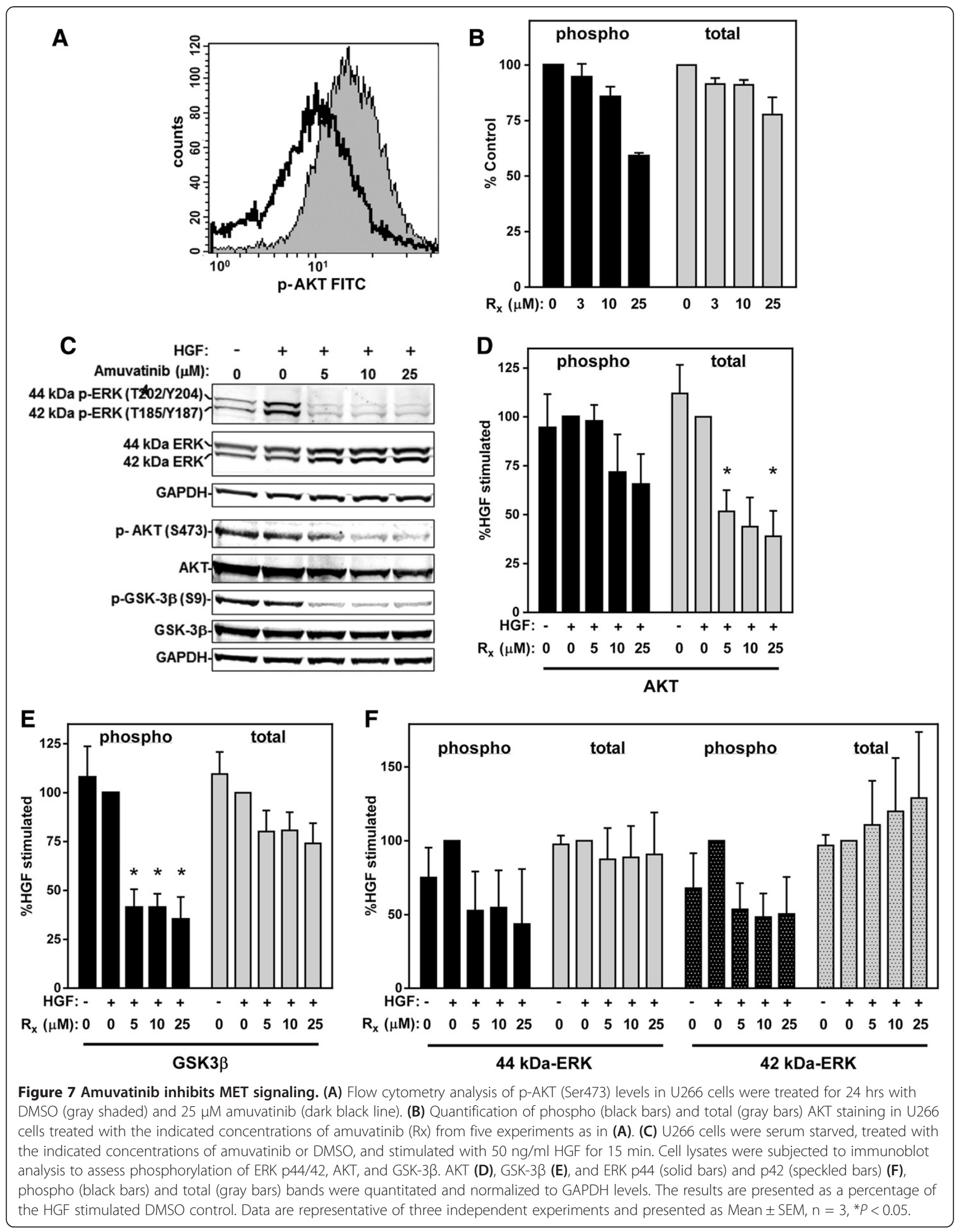


in cell death in U266 myeloma cell line dependent on MET/HGF signaling, as measured by annexin V/PI staining and PARP cleavage. This cytotoxic effect remained even when these MET-addicted cells were grown on bone marrow stromal cells. In contrast, the drug did not induce apoptosis in another myeloma cell line (RPMI-8226/S) that is not dependent on the MET/HGF signaling axis due to lower levels of HGF (75\% less) and MET (95\% less).

Because amuvatinib also impairs KIT and PDGFR signaling, we tested impact of imatinib (an established KIT and PDGFR inhibitor) in myeloma cells. Imatinib induced no significant amount of cell death in U266 cells demonstrating that amuvatinib's effect was due to MET inhibition. This statement was in line with the data regarding decreased phosphorylation of MET after amuvatinib treatment. Because $>95 \%$ of the compound is bound and sequestered by serum proteins (Unpublished data), the dose required to achieve maximum inhibition of MET phosphorylation in serum starved conditions was lower than the dose to induce apoptosis in full serum conditions. Likewise, under serum starved conditions, the maximum induction of apoptosis was seen at the same dose which achieved maximum inhibition of MET phosphorylation. As expected, in imatinib treated cells, there was no reduction of p-MET (data not shown) as well as no significant reduction in survival. These correlation data suggest that amuvatinib mediated growth inhibition and cell death is due to its action on MET and not its action on KIT or PDGFR.

In conjunction with a decrease in MET phosphorylation, there was a decline in HGF-dependent ERK1/2 and AKT phosphorylation as well as the phosphorylation of the AKT targets GSK3 $\beta$ and caspase-9 (data not shown). Diminution of phosphorylated MET and associated decreases in ERK1/2 and AKT phosphorylation has been shown to be important in growth, migration and cell survival pathways for other cancer cell types [11].

Amuvatinib proved to be effective in inducing cell death not only in a MET dependent myeloma cell line but also in primary CD138+ malignant plasma cells obtained from patients with myeloma. In contrast, amuvatinib did not cause cell death in normal CD138- cells obtained from the same individuals (Figure 2). These data provide evidence of the selectivity of amuvatinib, suggesting that it may be used specifically for myeloma treatment without impairing other normal hematological cells in the bone marrow. In line with this selective cytotoxic effect on CD138 plasma cells, MET phosphorylation was reduced by amuvatinib treatment in primary plasma cells but not CD138- cells.

The effects of amuvatinib described here provide proof-of-concept that MET is important for the survival of myeloma cells and that reduction of its kinase activity may prove to be an effective targeted therapy. The $25 \mu \mathrm{M}$ dose of amuvatinib needed to robustly induce apoptosis in cell lines and plasma cells under full serum conditions may not be achievable in vivo. Pharmacokinetic studies of amuvatinib during a phase I trial indicated that plasma levels reached between 1 and $2 \mu \mathrm{M}$ [51]. Hence, newer generation and more potent MET tyrosine kinase inhibitors are needed [11]. ARQ 197 (tivantinib) is a smallmolecule, non-ATP-competitive inhibitor which is highly specific for MET [52,53]. This drug is well tolerated in clinical trials and has shown efficacy in solid tumors [54-58]. Pharmacodynamic studies from a phase I trial indicated that at an oral dosing of $360 \mathrm{mg}$, twice daily, ARQ 197 reached steady-state plasma concentrations of 6-7 $\mu \mathrm{M}$ [55]. This correlated with decreases in total MET and phospho-FAK (Tyr861) and increases in TUNEL-positive cells in patients' tumors.

Our results with amuvatinib provided the impetus to pursue testing of ARQ 197 in myeloma cells. Our preclinical studies indicated that treatment with ARQ 197 for 48 hours was cytotoxic to myeloma cell lines ( $\geq 60 \%$ increase in annexin V/PI-positive cells) at clinically achievable doses [59]. Moreover, these studies provided the foundation for a Cancer Therapy Evaluation Program, National Cancer Institute sponsored phase 2 clinical trial of ARQ 197 in myeloma patients, which is currently underway at MD Anderson Cancer Center [60].

\section{Conclusions}

Our finding provides proof-of-principle that MET is important for the survival of myeloma cells and using a MET inhibitor such as amuvatinib may prove to be an effective strategy for treatment of MM. Amuvatinib exhibited tumoricidal activity in myeloma cells which was associated with inhibition of MET signaling. Amuvatinib's lack of effect on CD138- cells from the same patients further establishes the selectivity of this agent. The clinical success of other targeted therapeutics for cytoplasmic and receptor tyrosine kinases, further underscores a need for testing a small-molecule inhibitor that targets MET kinase activity for patients with myeloma.

\section{Methods}

\section{Materials}

Amuvatinib (MP470) was obtained from Astex Pharmaceuticals, Inc. (Dublin, CA) and was dissolved in DMSO (Sigma Aldrich, St. Louis, MO). Because of stability constraints, amuvatinib solution was prepared fresh for each experiment. Imatinib was purchased from Novartis (St. Louis, MO) and was dissolved in DMSO and stored in aliquots at $-20^{\circ} \mathrm{C}$. $\left[{ }^{3} \mathrm{H}\right]$ thymidine $(60 \mathrm{Ci} / \mathrm{mmol})$ was obtained from Moravek Biochemical Inc. (Brea, CA).

\section{Cell culture and growth analysis}

The myeloma cell lines U266 [61] and RPMI-8226/S [62] were obtained from Dr. William Dalton at H. Lee 
Moffitt Cancer Center (Tampa, FL). NK-tert human bone marrow stromal cells were obtained from Dr. Jan Burger at UT MD Anderson Cancer Center [63]. The cell lines were maintained as described [32,63] and routinely tested for Mycoplasma infection and authenticated by short tandem repeat analysis by UT MD Anderson Cancer Center's Characterized Cell Line Core facility.

Myeloma cell-stromal co-cultures were performed using U266 cells and NK-tert cells at a ratio of 20 to 1 . Stromal cells were plated at a concentration of $\sim 2 \times 10^{2}$ cells $/ \mathrm{mm}^{2}$ surface area 5 hours before adding U266 cells at a 20 fold higher concentration. The cells were co-cultured for $2 \mathrm{~h}$ prior to treatment with or without amuvatinib or bortezomib for $48 \mathrm{~h}$. At the end of incubation, the U266 cells, which are free floating in these cultures, were carefully removed for analysis, leaving the adherent stromal layer undisturbed. Additionally, the stromal cells were also harvested by trypsinization and similarly assessed.

The effect of amuvatinib treatment on cell growth inhibition was measured in exponentially growing U266 cells. Cells were counted using a Coulter counter (Beckman Coulter, Fullerton, CA). DNA synthesis was measured using $\left[{ }^{3} \mathrm{H}\right]$ thymidine incorporation as described [64].

\section{Gene expression array analyses}

Expression data from 162 CD138+ bone marrow plasma cell samples from healthy individuals as well as patients with MGUS, SMM, MM-N, and MM-R, which were measured by using Affymetrix U133A microarrays, were downloaded from GEO (GSE6477) [40,41]. Robust Multichip Average (RMA) algorithm was used for normalization/ quantification of the data. The maximal values for the respective probe-sets of $M E T$ and $H G F$ were used for gene expression profiling. The Kruskal-Wallis test was applied to assess whether expression of MET and HGF was associated with defined clinical groups, and results are presented as box-plots.

\section{Isolation of CD138+ AND CD138- cells from primary bone marrow aspirates from MM patients}

Primary samples were obtained from both male and female myeloma patients being treated at MD Anderson Cancer Center (Table 1). Patient samples were obtained using an MD Anderson Cancer Center Institutional Review Board approved protocol. All patients signed an informed consent form to provide peripheral blood and bone marrow samples. After collection of bone marrow samples, CD138+ cells were isolated as described [65], suspended in RPMI 1640 with 10\% human AB serum (Cambrex Biosciences, East Rutherford, NJ) and used immediately for experiments. Peripheral blood samples were collected from patients 2, 4, and 5 for assessment of plasma HGF levels.

\section{Immunoblot analysis}

The effects of amuvatinib on HGF dependent signaling were assessed in U266 cells that had been serum starved for $24 \mathrm{~h}$ in RPMI 1640 containing $0.1 \%$ FBS; for the last $16 \mathrm{~h}$ of starvation the cells were treated with various concentrations of amuvatinib or DMSO. They were then treated with $50 \mathrm{ng} / \mathrm{ml} \mathrm{HGF}$ for $15 \mathrm{~min}$ to stimulate MET. Amuvatinib-mediated induction of PARP cleavage was performed on U266 cells cultured in full serum (10\% FBS) as well as under low serum conditions $(0.1 \%$ FBS). Protein lysates and immunoblots were prepared as previously described [66]. Experiments were performed in triplicates, and bands were quantified by using an Odyssey Infrared Imaging System (LI-COR Biosciences, Lincoln, NE). Primary antibodies were: mouse monoclonal antibodies to MET clone 3D4 (Invitrogen, Carlsbad, CA); GSK-3 $\beta$ clone 7/GSK-3b, PARP clone C2-10, cleaved PARP Asp 214 clone F21-852, AKT clone 9Q7 (BD Biosciences Pharmingen, San Diego, CA); GAPDH clone 6C6 (Abcam, Inc, Cambridge, MA); phosphoERK1/2 (Thr202/Tyr204) clone E10 (Cell Signaling Technology, Danvers, MA); $\beta$-actin clone AC-15 (Sigma Aldrich); rabbit monoclonal antibodies to phospho-GSK$3 \beta$ (Ser9) clone 5B3 (Cell Signaling Technology); rabbit polyclonal antibodies to phospho-MET (Tyr1349) (Invitrogen); ERK1/2, and phospho-AKT (Ser473) (Cell Signaling Technology).

\section{Flow cytometry}

Intracellular protein expression in U266 cells was measured using BD Cytofix/Cytoperm Fixation/Permeabilization Kit (BD Biosciences). Primary antibodies used were anti-phospho-HGF R/c-MET (Tyr1234/ 1235) (R\&D Systems, Minneapolis, MN), MET (C-12): sc-10 (Santa Cruz Biotechnology, Santa Cruz, CA), phospho-AKT (Ser473), AKT antibody (Cell Signaling Technology); and caspase-9 (Ser196) (Santa Cruz Biotechnology). Secondary antibody was a fluorescein isothiocyanate-conjugated (FITC) Affinipure goat antirabbit (Jackson ImmunoResearch, West Grove, PA). Cell cycle analysis and annexin V/propidium iodide (PI) staining were performed, respectively, as described [32,33]. All flow cytometry analysis was performed using a Becton Dickinson FACSCalibur flow cytometer (San Jose, CA, USA). Statistical significance of changes was assessed by paired $t$-test analysis using Prism software (Graphpad, San Diego, CA).

\section{Enzyme linked-immuno-sorbent assay for HGF levels}

HGF levels in primary patient plasma were determined using the Human HGF Immunoassay Kit as per the manufacturer's protocol (Invitrogen). The absorbance of this horseradish-peroxidase based assay was measured at $450 \mathrm{~nm}$. Each sample was assayed in triplicate. 


\section{Additional file}

Additional file 1: Figure S1. MET and HGF expression. Real-time RT-PCR analysis of HGF and MET transcript levels in U266 and RPMI-8226/S cells. Figure S2. (A) NK-tert cells protect U266 cells from bortezomib-induced cytotoxicity. (B) MET expression and HGF-dependent activity in serum starved NK-tert cells.

\section{Abbreviations}

DMSO: Dimethyl sulfoxide; ERK: Extracellular signal-regulated kinases; FBS: Fetal bovine serum; GSK3 $\beta$ : Glycogen synthase kinase $3 \beta$; HGF: Hepatocyte growth factor; IL-6: Interleukin-6; MAPK: Mitogen-activated protein kinase; MGUS: Monoclonal gammopathy of undetermined significance; MM: Multiple myeloma; MM-N: Newly-diagnosed multiple myeloma; MM-R: Relapsed/refractory disease; PARP: Poly ADP ribose polymerase; PDGFR: Platelet derived growth factor receptor; PI: Propidium iodide; SMM: Smoldering multiple myeloma.

\section{Competing interest}

SR and PT are employed by Astex Pharmaceuticals, Inc., Dublin, CA. For the remaining authors, none was declared.

\section{Authors' contributions}

CJP, SZ, KB, and CMS designed and performed experiments; CJP, SZ, JZ, VB, and CMS analyzed data; SS performed experiments; PT and SR provided amuvatinib; MW provide sorted bone marrow samples; CJP and CMS wrote the manuscript; CMS and VG directed study; VG provided laboratory resources; All authors critically read and approved manuscript.

\section{Authors' information}

Christine Marie Stellrecht and Varsha Gandhi contributed equally as senior authors.

\section{Acknowledgements}

This work was supported in part by grants from the National Institutes of Health [Minority Graduate Student Supplement NIH RO1-CA85915 to CJP], the National Cancer Institute [Cancer Center Support Grant NIH P50 CA16672; and MD Anderson Cancer Center SPORE in Multiple Myeloma Research NIH P50 CA142509 to VB and MW], the Center for Targeted Therapy to CMS and VG, and Multiple Myeloma Research Foundation Senior Research Award to CMS.

The authors are grateful to David Graber for processing the bone marrow samples and separating the CD138+ cells and to Jairo A Matthews for coordinating patient sample collection distributing these samples to our laboratory.

\section{Author details}

${ }^{1}$ Departments of Experimental Therapeutics, The University of Texas MD Anderson Cancer Center, Houston, Texas, USA. ${ }^{2}$ Bioinformatics and Computational Biology, The University of Texas MD Anderson Cancer Center, Houston, Texas, USA. ${ }^{3}$ Biostatistics, The University of Texas MD Anderson Cancer Center, Houston, Texas, USA. ${ }^{4}$ Leukemia, The University of Texas MD Anderson Cancer Center, Houston, Texas, USA. ${ }^{5}$ Lymphoma/Myeloma, The University of Texas MD Anderson Cancer Center, Houston, Texas, USA ${ }^{6}$ Graduate School of Biomedical Sciences, The University of Texas Health Science Center, Houston, Texas, USA. ${ }^{7}$ Astex Pharmaceuticals, Inc., Dublin, California, USA.

Received: 3 November 2013 Accepted: 2 December 2013 Published: 10 December 2013

\section{References}

1. Hallek M, Bergsagel PL, Anderson KC: Multiple myeloma: increasing evidence for a multistep transformation process. Blood 1998, 91:3-21.

2. Piazza FA, Gurrieri C, Trentin L, Semenzato G: Towards a new age in the treatment of multiple myeloma. Ann Hematol 2007, 86:159-172.

3. Mahindra A, Laubach J, Raje N, Munshi N, Richardson PG, Anderson K: Latest advances and current challenges in the treatment of multiple myeloma. Nat Rev Clin Oncol 2012, 9:135-143.
4. Raab MS, Podar K, Breitkreutz I, Richardson PG, Anderson KC: Multiple myeloma. Lancet 2009, 374:324-339.

5. Roodman GD: Targeting the bone microenvironment in multiple myeloma. J Bone Miner Metab 2010, 28:244-250.

6. Podar K, Anderson KC: The pathophysiologic role of VEGF in hematologic malignancies: therapeutic implications. Blood 2005, 105:1383-1395.

7. Derksen PW, De Gorter DJ, Meijer HP, Bende RJ, Van Dijk M, Lokhorst HM, Bloem AC, Spaargaren M, Pals ST: The hepatocyte growth factor/Met pathway controls proliferation and apoptosis in multiple myeloma. Leukemia 2003, 17:764-774.

8. Yasui $H$, Hideshima T, Richardson PG, Anderson KC: Novel therapeutic strategies targeting growth factor signalling cascades in multiple myeloma. Br J Haematol 2006, 132:385-397.

9. Hideshima T, Podar K, Chauhan D, Anderson KC: Cytokines and signal transduction. Best Pract Res Clin Haematol 2005, 18:509-524.

10. Song $L$, Li Y, Sun $Y X, Y u$ M, Shen BF: IL-6 inhibits apoptosis of human myeloma cell line XG-7 through activation of JAK/STAT pathway and up-regulation of Mcl-1. Ai Zheng 2002, 21:113-116.

11. Stellrecht $C M$, Gandhi V: MET receptor tyrosine kinase as a therapeutic anticancer target. Cancer Lett 2009, 280:1-14.

12. Naldini L, Vigna E, Ferracini R, Longati P, Gandino L, Prat M, Comoglio PM: The tyrosine kinase encoded by the MET proto-oncogene is activated by autophosphorylation. Mol Cell Biol 1991, 11:1793-1803.

13. Naldini L, Vigna E, Narsimhan RP, Gaudino G, Zarnegar R, Michalopoulos GK, Comoglio PM: Hepatocyte growth factor (HGF) stimulates the tyrosine kinase activity of the receptor encoded by the proto-oncogene c-MET. Oncogene 1991, 6:501-504.

14. Rodrigues GA, Park M: Autophosphorylation modulates the kinase activity and oncogenic potential of the Met receptor tyrosine kinase. Oncogene 1994, 9:2019-2027.

15. Derksen PW, Keehnen RM, Evers LM, van Oers MH, Spaargaren M, Pals ST: Cell surface proteoglycan syndecan-1 mediates hepatocyte growth factor binding and promotes Met signaling in multiple myeloma. Blood 2002, 99:1405-1410.

16. Tjin EPM, Groen RWJ, Vogelzang I, Derksen PWB, Klok MD, Meijer HP, van Eeden S, Pals ST, Spaargaren M: Functional analysis of HGF/MET signaling and aberrant HGF-activator expression in diffuse large B-cell lymphoma. Blood 2006, 107:760-768.

17. Hennessy BT, Smith DL, Ram PT, Lu Y, Mills GB: Exploiting the PI3K/AKT pathway for cancer drug discovery. Nat Rev Drug Discov 2005, 4:988-1004.

18. Borset M, Hjorth-Hansen H, Seidel C, Sundan A, Waage A: Hepatocyte growth factor and its receptor c-met in multiple myeloma. Blood 1996 88:3998-4004.

19. Borset M, Lien E, Espevik T, Helseth E, Waage A, Sundan A: Concomitant expression of hepatocyte growth factor/scatter factor and the receptor c-MET in human myeloma cell lines. J Biol Chem 1996, 271:24655-24661

20. Seidel C, Borset M, Turesson I, Abildgaard N, Sundan A, Waage A: Elevated serum concentrations of hepatocyte growth factor in patients with multiple myeloma. The nordic myeloma study group. Blood 1998 91:806-812.

21. Seidel C, Borset M, Hjertner O, Cao D, Abildgaard N, Hjorth-Hansen H, Sanderson RD, Waage A, Sundan A: High levels of soluble syndecan-1 in myeloma-derived bone marrow: modulation of hepatocyte growth factor activity. Blood 2000, 96:3139-3146.

22. Iwasaki T, Hamano T, Ogata A, Hashimoto N, Kitano M, Kakishita E: Clinical significance of vascular endothelial growth factor and hepatocyte growth factor in multiple myeloma. Br J Haematol 2002, 116:796-802.

23. Seidel C, Lenhoff S, Brabrand S, Anderson G, Standal T, Lanng-Nielsen J, Turesson I, Borset M, Waage A: Hepatocyte growth factor in myeloma patients treated with high-dose chemotherapy. Br J Haematol 2002, 119:672-676.

24. Alexandrakis MG, Passam FH, Sfiridaki A, Kandidaki E, Roussou P, Kyriakou DS: Elevated serum concentration of hepatocyte growth factor in patients with multiple myeloma: correlation with markers of disease activity. Am J Hematol 2003, 72:229-233.

25. Kara IO, Sahin B, Gunesacar R, Unsal C: Clinical significance of hepatocyte growth factor, platelet-derived growth factor- $A B$, and transforming growth factor-alpha in bone marrow and peripheral blood of patients with multiple myeloma. Adv Ther 2006, 23:635-645. 
26. Sezer O, Jakob C, Eucker J, Niemoller K, Gatz F, Wernecke K, Possinger K: Serum levels of the angiogenic cytokines basic fibroblast growth factor (bFGF), vascular endothelial growth factor (VEGF) and hepatocyte growth factor (HGF) in multiple myeloma. Eur J Haematol 2001, 66:83-88.

27. Pour L, Svachova H, Adam Z, Mikulkova Z, Buresova L, Kovarova L, Buchler T, Penka M, Vorlicek J, Hajek R: Pretreatment hepatocyte growth factor and thrombospondin-1 levels predict response to high-dose chemotherapy for multiple myeloma. Neoplasma 2010, 57:29-34.

28. Ludek P, Hana S, Zdenek A, Martina A, Dana K, Tomas B, Lucie K, Marta K, Jaroslav M, Miroslav $P$, et al: Treatment response to bortezomib in multiple myeloma correlates with plasma hepatocyte growth factor concentration and bone marrow thrombospondin concentration. Eur J Haematol 2010, 84:332-336.

29. Pour L, Svachova H, Adam Z, Almasi M, Buresova L, Buchler T, Kovarova L, Nemec P, Penka M, Vorlicek J, Hajek R: Levels of angiogenic factors in patients with multiple myeloma correlate with treatment response. Ann Hematol 2010, 89:385-389.

30. Hjertner $\mathrm{O}$, Torgersen ML, Seidel C, Hjorth-Hansen $\mathrm{H}$, Waage A, Borset M, Sundan A: Hepatocyte growth factor (HGF) induces interleukin-11 secretion from osteoblasts: a possible role for HGF in myeloma-associated osteolytic bone disease. Blood 1999, 94:3883-3888.

31. Standal T, Abildgaard N, Fagerli UM, Stordal B, Hjertner O, Borset M, Sundan A: HGF inhibits BMP-induced osteoblastogenesis: possible implications for the bone disease of multiple myeloma. Blood 2007, 109:3024-3030.

32. Stellrecht CM, Phillip CJ, Cervantes-Gomez F, Gandhi V: Multiple myeloma cell killing by depletion of the MET receptor tyrosine kinase. Cancer Res 2007, 67:9913-9920.

33. Phillip CJ, Stellrecht CM, Nimmanapalli R, Gandhi V: Targeting MET transcription as a therapeutic strategy in multiple myeloma. Cancer Chemother Pharmacol 2009, 63:587-597.

34. Chen LS, Stellrecht CM, Gandhi V: RNA-directed agent, cordycepin, induces cell death in multiple myeloma cells. Br J Haematol 2008, 140:682-691.

35. Mahtouk K, Tjin EP, Spaargaren M, Pals ST: The HGF/MET pathway as target for the treatment of multiple myeloma and B-cell lymphomas. Biochim Biophys Acta 1806, 2010:208-219.

36. Qi W, Cooke L, Calaluce R, Bearss D, Mahadevan D: Dual inhibition of receptor tyrosine kinases of PDGFR and EGFR abolishes prostate cancer cell growth in a mouse xenograft model by complete dephosphorylation of PKB/Akt. Proc Am Assoc Cancer Res 2007, 48:5421.

37. Tibes R, Berk Gl, Fine GD, Choy GS, Tolcher AW: A phase-1 study of MP-470, a novel orally bioavailable small molecule with Rad51 suppression activity. Proc Am Assoc Cancer Res 2008, 49:4083.

38. Tolcher AW, Berk Gl, Fine GD, Choy GD, Bearss DJ, Redkar S, Tibes R: MP470, a potent oral Rad51 suppressor is safe and tolerable in first-in-human study. Proc Am Assoc Cancer Res 2008, 49:4083.

39. Mahtouk K, Moreaux J, Hose D, Reme T, Meissner T, Jourdan M, Rossi JF, Pals ST, Goldschmidt H, Klein B: Growth factors in multiple myeloma: a comprehensive analysis of their expression in tumor cells and bone marrow environment using Affymetrix microarrays. BMC Cancer 2010, 10:198.

40. Chng WJ, Kumar S, Vanwier S, Ahmann G, Price-Troska T, Henderson K Chung TH, Kim S, Mulligan G, Bryant B, et al: Molecular dissection of hyperdiploid multiple myeloma by gene expression profiling. Cancer Res 2007, 67:2982-2989

41. Keats JJ, Fonseca R, Chesi M, Schop R, Baker A, Chng WJ, Van Wier S, Tiedemann R, Shi CX, Sebag M, et al: Promiscuous mutations activate the noncanonical NF-kappaB pathway in multiple myeloma. Cancer Cell 2007, 12:131-144.

42. Meads MB, Hazlehurst LA, Dalton WS: The bone marrow microenvironment as a tumor sanctuary and contributor to drug resistance. Clin Cancer Res 2008, 14:2519-2526.

43. Zhang W, Huang P: Cancer-stromal interactions: role in cell survival metabolism and drug sensitivity. Cancer Biol Ther 2011, 11:150-156.

44. Druker BJ: Imatinib as a paradigm of targeted therapies. Adv Cancer Res 2004, 91:1-30

45. Rodrigues GA, Naujokas MA, Park M: Alternative splicing generates isoforms of the met receptor tyrosine kinase which undergo differential processing. Mol Cell Biol 1991, 11:2962-2970.
46. Hov H, Holt RU, Ro TB, Fagerli UM, Hjorth-Hansen H, Baykov V, Christensen JG, Waage A, Sundan A, Borset M: A selective c-met inhibitor blocks an autocrine hepatocyte growth factor growth loop in ANBL-6 cells and prevents migration and adhesion of myeloma cells. Clin Cancer Res 2004 10:6686-6694

47. Tolcher AW, Mita M, Gordon M, Rosen L, Patnaik A, Mita A, Fine GD, Choy GS, Berk Gl: Clinical responses in highly refractory solid tumor patients with oral MP-470, a multi-targeted tyrosine kinase inhibitor, in combination with standard of care chemotherapy regimens: preliminary report from a multi-institutional phase-lb clinical trial. Proc Am Assoc Cancer Res 2008, 49:403.

48. Mahadevan D, Cooke L, Riley C, Swart R, Simons B, Della Croce K, Wisner L, lorio M, Shakalya K, Garewal H, et al: A novel tyrosine kinase switch is a mechanism of imatinib resistance in gastrointestinal stromal tumors. Oncogene 2007, 26:3909-3919.

49. Trevor K, Combs D, Mahadevan D, Bearss D, Cranmer L: Activity of the multi-targeted, receptor tyrosine kinase inhibitor MP470 against synovial sarcoma cells. Proc Am Assoc Cancer Res 2008, 49:4891

50. Welsh JW, Mahadevan D, Ellsworth R, Cooke L, Bearss D, Stea B: The c-Met receptor tyrosine kinase inhibitor MP470 radiosensitizes glioblastoma cells. Radiat Oncol 2009, 4:69.

51. Tibes R, Fine G, Choy G, Redkar S, Taverna P, Oganesian A, Sahai A, Azab M, Tolcher AW: A phase I, first-in-human dose-escalation study of amuvatinib, a multi-targeted tyrosine kinase inhibitor, in patients with advanced solid tumors. Cancer Chemother Pharmacol 2013, 71:463-471.

52. Munshi N, Jeay S, Li Y, Chen CR, France DS, Ashwell MA, Hill J, Moussa MM Leggett DS, Li CJ: ARQ 197, a novel and selective inhibitor of the human c-Met receptor tyrosine kinase with antitumor activity. Mol Cancer Ther 2010, 9:1544-1553

53. Eathiraj S, Palma R, Volckova E, Hirschi M, France DS, Ashwell MA, Chan TC: Discovery of a novel mode of protein kinase inhibition characterized by the mechanism of inhibition of human mesenchymal-epithelial transition factor (c-Met) protein autophosphorylation by ARQ 197. J Biol Chem 2011, 286:20666-20676.

54. Sequist LV, von Pawel J, Garmey EG, Akerley WL, Brugger W, Ferrari D, Chen Y, Costa DB, Gerber DE, Orlov S, et al: Randomized phase II study of erlotinib plus tivantinib versus erlotinib plus placebo in previously treated non-small-cell lung cancer. J Clin Oncol 2011, 29:3307-3315.

55. Yap TA, Olmos D, Brunetto AT, Tunariu N, Barriuso J, Riisnaes R, Pope L, Clark J, Futreal A, Germuska M, et al: Phase I trial of a selective c-MET inhibitor ARQ 197 incorporating proof of mechanism pharmacodynamic studies. J Clin Oncol 2011, 29:1271-1279.

56. Goldman JW, Laux I, Chai F, Savage RE, Ferrari D, Garmey EG, Just RG, Rosen LS: Phase 1 dose-escalation trial evaluating the combination of the selective MET (mesenchymal-epithelial transition factor) inhibitor tivantinib (ARQ 197) plus erlotinib. Cancer 2012, 118:5903-5911.

57. Previdi S, Abbadessa G, Dalo F, France DS, Broggini M: Breast cancer-derived bone metastasis can be effectively reduced through specific c-MET inhibitor tivantinib (ARQ 197) and shRNA c-MET knockdown. Mol Cancer Ther 2012, 11:214-223.

58. Wagner AJ, Goldberg JM, Dubois SG, Choy E, Rosen L, Pappo A, Geller J, Judson I, Hogg D, Senzer N, et al: Tivantinib (ARQ 197), a selective inhibitor of MET, in patients with microphthalmia transcription factor-associated tumors: results of a multicenter phase 2 trial. Cancer 2012, 118:5894-5902.

59. Zaman S, Stellrecht CM, Shentu S, Orlowski R, Gandhi V: Targeting the pro-survival protein c-MET with ARQ 197 inhibits growth of multiple myeloma cells. Proc Am Assoc Cancer Res 2012, 53:844

60. Dorkhom SJ, Zaman S, Thomas SK, Alexanian R, Shah JJ, Weber DM, Wang $\mathrm{M}$, Anderson ML, Baladandayuthapani $\mathrm{V}$, Lin $\mathrm{YH}$, et al: Phase II study of the c-Met inhibitor ARQ 197 (tivantinib) in patients with relapsed multiple myeloma. Blood (ASH Annual Meeting Abstracts) 2012, 120:2976.

61. Catlett-Falcone R, Landowski TH, Oshiro MM, Turkson J, Levitzki A, Savino R, Ciliberto G, Moscinski L, Fernandez-Luna JL, Nunez G, et al: Constitutive activation of Stat3 signaling confers resistance to apoptosis in human U266 myeloma cells. Immunity 1999, 10:105-115.

62. Bellamy WT, Dalton WS, Gleason MC, Grogan TM, Trent JM: Development and characterization of a Melphalan-resistant human multiple myeloma cell line. Cancer Res 1991, 51:995-1002.

63. Manshouri T, Estrov Z, Quintas-Cardama A, Burger J, Zhang Y, Livun A, Knez L, Harris D, Creighton CJ, Kantarjian HM, Verstovsek S: Bone marrow 
stroma-secreted cytokines protect JAK2(V617F)-mutated cells from the effects of a JAK2 inhibitor. Cancer Res 2011, 71:3831-3840.

64. Gandhi V, Ayres M, Halgren RG, Krett NL, Newman RA, Rosen ST:

8-chloro-cAMP and 8-chloro-adenosine act by the same mechanism in multiple myeloma cells. Cancer Res 2001, 61:5474-5479.

65. Bjorklund CC, Ma W, Wang ZQ, Davis RE, Kuhn DJ, Kornblau SM, Wang ML, Shah JJ, Orlowski RZ: Evidence of a role for activation of Wnt/b-catenin signaling in the resistance of plasma cells to lenalidomide. $J$ Biol Chem 2011, 286:11009-11020.

66. Stellrecht CM, Ayres M, Arya R, Gandhi V: A unique RNA-directed nucleoside analog is cytotoxic to breast cancer cells and depletes cyclin E levels. Breast Cancer Res Treat 2010, 121:355-364.

doi:10.1186/1756-8722-6-92

Cite this article as: Phillip et al: Targeting MET kinase with the

small-molecule inhibitor amuvatinib induces cytotoxicity in primary myeloma cells and cell lines. Journal of Hematology \& Oncology 2013 6:92.

\section{Submit your next manuscript to BioMed Central and take full advantage of:}

- Convenient online submission

- Thorough peer review

- No space constraints or color figure charges

- Immediate publication on acceptance

- Inclusion in PubMed, CAS, Scopus and Google Scholar

- Research which is freely available for redistribution 